\title{
KEMAMPUAN PENALARAN MATEMATIKA DAN SELF-EFFICACY SISWA SMP
}

\author{
Aprisal $^{1)}$, Sartika Arifin ${ }^{2}$, \\ ${ }^{1,2)}$ Universitas Sulawesi Barat, Jalan Prof. Dr. Baharuddin Lopa, S. H., Baurung, Banggae Timur, Majene, \\ Sulawesi Barat; \\ ${ }^{1)}$ aprisal@unsulbar.ac.id: ${ }^{2)}$ sartikaarifin91@unsulbar.ac.id
}

Received : 30/12/2019

Accepted : $29 / 01 / 2020$

Published : 31/01/2020

\begin{abstract}
This study is a survey research using quantitative approach. The subject in this study was eighth grade students with 132 students. Data in this study were collected using two instruments, namely mathematics reasoning ability tests and self-efficacy questionnaires. Analysis of the data in this study was divided into two parts, namely descriptive analysis and inferential analysis. Descriptive analysis described of mathematical reasoning ability and self-efficacy. Inferential analysis used Pearson product moment correlation test to find relationship between self-efficacy and mathematical reasoning ability. The results of the study showed that the students' self-efficacy was in high category and the strength aspect was the dimension of self-efficacy with the highest score. In mathematical reasoning ability, the ability of students to give correct and complete evidence of solutions has the highest score. The result of correlation test showed that there was relationship between self-efficacy and mathematical reasoning ability with a positive relationship.
\end{abstract}

Keywords: self-efficacy, mathematical reasoning

\begin{abstract}
Abstrak
Penelitian ini merupakan penelitian survei dengan pendekatan kuantitatif. Subjek pada penelitian ini adalah siswa kelas VIII SMP dengan jumlah siswa 132 siswa. Data pada penelitian ini dikumpulkan dengan menggunakan dua instrumen yaitu tes kemampuan penalaran matematika dan angket self-efficacy. Analisis data pada penelitian terbagi atas dua bagian yaitu analisis deskriptif dan analisis inferensial. Analisis deskriptif menggambarkan kondisi kemampuan penalaran matematika dan self-efficacy secara keseluruhan. Sementara itu, analisis inferensial menggunakan uji korelasi Pearson product moment untuk mengetahui hubungan antara selfefficacy dan kemampuan penalaran matematika. Hasil analisis data menunjukkan bahwa self-efficacy siswa berada pada kategori tinggi dan aspek strength merupakan dimensi self-efficacy dengan skor tertinggi. Pada penalaran matematika, kemampuan siswa memberikan bukti yang benar dan lengkap terhadap solusi mempunyai skor rata-rata yang paling tinggi. Hasil uji korelasi diperoleh hasil bahwa terdapat hubungan antara self-efficacy dan kemampuan penalaran matematika dengan arah hubungan yang positif.
\end{abstract}

Kata Kunci: self-efficacy, penalaran matematika

\section{Pendahuluan}

Matematika merupakan mata pelajaran yang membantu siswa mengembangkan sejumlah soft-skill diantaranya: kemampuan berpikir logis, kemampuan analitis, kemampuan berpikir kritis dan kreatif serta kemampuan team-work siswa (Depdiknas, 2006). Menghadapi era revolusi industri 4.0, salah satu kemampuan matematika yang paling dibutuhkan adalah kemampuan penalaran matematika siswa. Sejalan dengan tujuan pembelajaran matematika yang terlaksana bahwa matematika diajarkan agara siswa memiliki kemampuan diantaranya 
kemampuan penalaran (NCTM, 2000). Penalaran penting dalam pembelajaran matematika karena penalaran membantu siswa untuk membangun dan mengembangkan kemampuan akademiknya (John \& Mst, 2016). Oleh karena itu, penalaran dan matematika adalah dua hal yang tidak bisa dipisahkan karena memahami matematika dengan baik dapat melalui penalaran (Maarif, 2016).

Namun demikian, berdasarkan data yang ada pentingnya penalaran tidak sejalan dengan kondisi pembelajaran matematika. Berdasarkan asesmen yang dilakukan oleh TIMSS pada tahun 2011 menunjukkan bahwa rata-rata skor matematika yang diperoleh siswa berada pada poin 386 dari rata-rata skor matematika siswa di dunia yaitu 500. Lebih spesifik menunjukkan bahwa kemampuan siswa Indonesia dalam menggunakan penalaran menyelesaikan masalah masih tergolong rendah (Mullis, Martin, Hoy, \& Arora, 2012). Fakta lain di lapangan (salah satu sekolah tingkat menengah pertama) menunjukkan bahwa siswa kesulitan menyelesaikan soal yang berkaitan penalaran. Hal ini terlihat ketika siswa diminta menyelesaikan soal matematika yang berbeda dari yang biasa dicontohkan oleh guru.

Penalaran didefinisikan sebaagai kegiatan mengidentifikasi pola dan sifat, menyelesaikan masalah matematika dengan memanipulasi proses prosedural, membuat generalisasi, memberikan bukti serta menjelaskan kesimpulan dari pernyataan matematika. Tujuan akhir dari penalaran matematika adalah membuat suatu kesimplan berdasarkan gejala-gejala matematik (NCTM, 2000). Selain itu, kesimpulan yang terbentuk pada proses penalaran berdasarkan pengetahuan siswa sebelumnya (Conner, Singletary, Smith, Wagner, \& Fransisco, 2014). Dalam kegiatan bernalar tidak terlepas dari cara berpikir induktif dan deduktif untuk membuat kesimpulan (Santrock, 2011). Berpikir induktif maupun deduktif dalam penalaran matematika terdiri dari beberapa bentuk seperti memberikan penjelasan, menjustifikasi, memprediksi atau mengajukan dugaan. Dalam hal yang lebih luas kegiatan penalaran juga dapat sampai pada proses melakukan penelitian untuk memperoleh kesimpulan (Lim, Kim, Cordero, Buendia, \& Kasmer, 2015).

Merujuk pendapat beberapa ahli, maka pada penelitian ini digunakan indikator kemampuan penalaran matematik, yaitu (a) kemampuan menemukan pola, (b) kemampuan mengajukan dugaan, (c) kemampuan memberikan alasan terhadap suatu solusi (Aprisal \& Abadi, 2018a)

Pada pembelajaran matematika selain aspek kognitif, aspek afektif juga memiliki peranan penting yang mempengaruhi hasil belajar matematika siswa, salah satunya adalah self-efficacy (Malpass, O'neil, \& Hocevar, 2010). Self-efficacy adalah kepercayaan seseorang terhadap kemampuannya guna mencapai kesuksesan. Beberapa pendapat (Schunk \& Meece, 2006) mengungkapkan bahwa self-efficacy merupakan persepsi siswa terhadap kemampuannya dapat menyelesaikan tugas dengan baik. 
Berdasarkan definisi di atas, maka self-efficacy pada pembelajaran matematika berarti bahwa kemampuan siswa untuk menilai dirinya bahwa mereka mampu memecahkan masalah matematika, menyelesaikan soal matematika, ataupun berhasil pada program-program yang berkaitan dengan matematika (Betz \& Hackett, 1983). Pada beberapa penelitian menemukan bahwa terdapat hubungan positif antara kemampuan pedagogik dengan self-efficacy siswa (Phan, 2012). Siswa yang memiliki self-efficacy rendah cenderung memiliki nilai matematika yang rendah pula dan menghabiskan banyak waktu (Aprisal \& Abadi, 2018b). Sebaliknya siswa yang memiliki self-efficacy tinggi juga memiliki nilai matematika yang cenderung tinggi pula (Kitsantas, Cheema, \& Ware, 2011). Berdasarkan beberapa defisini di atas dapat disimpulkan bahwa self-efficacy adalah keyakinan siswa terhadap kemampuan sendiri untuk menyelesaikan masalah-masalah yang berkaitan dengan matematika.

Self-efficacy pada siswa dapat berasal dari empat sumber yaitu performance accomplishments, vicarious experience, verbal persuasion, dan emotional arousal zhwa selfefficacy ditentukan berdasarkan pengalaman akan kesuksesan atau keberhasilan siswa untuk menyelesaikan sejumlah tugas yang diberikan. Vicarious experiences hampir sama dengan Performance accomplishment, akan tetapi pada vicarious experiences berdasarkan pengalaman orang lain. Dengan melihat keberhasian orang lain dalam menyelesaikan tugas tertentu, rasa percaya diri akan kemampuannya juga akan tumbuh bahwa mereka yakin juga bisa. Verbal persuasion berupa tanggapan, komentar, atau penilaian orang lain (orang tua, guru, teman, dll). Tanggapan yang berupa komentar positif diyakini dapat menumbuhkan selfefficacy seseorang, sebaliknya komentar negatif juga dapat menurunkan self-efficacy siswa. Emottional arousal adalah reaksi psikis seseorang yang dapat mempengaruhi self-efficacy. Reaksi psikis tersebut antara lain perasaan cemas, stres, lelah, badmood (Lau, Kitsantas, Miller, \& Rodgers, 2018).

Selain tingkat/level self-efficacy siswa dipengaruhi oleh tiga aspek yaitu level (magnitude), strength, generality (Bandura, 2009). Level berarti tingkat self-efficacy siswa tergantung pada tingkat kesukaran atau kesulitan tugas-tugas yang dihadapi. Strength berkaitan dengan kekuatan dan keuletan siswa dalam memenuhi atau menyelesaikan tugas. Maksudnya adalah siswa mampu untuk bertahan lama ketika mengalami kesulitan menyelesaikan tugas. Generality berkaitan dengan keyakinan siswa menyelesaikan tugas di situasi yang berbeda. Situasi yang dimaksud adalah situasi pembelajaran misalkan menyelesaikan soal pada saat ujian, di depan kelas (presenstasi) dan sebagainya.

Berdasarkan uraian di atas, maka rumusan masalah pada penelitian ini, yaitu (1) bagaimana kemampuan penalaran matematika siswa. (2) bagaimana self-efficacy siswa. (3) adakah hubungan antara self-efficacy dan kemampuan penalaran matematika siswa. 


\section{Metode Penelitian}

Penelitian ini merupakan penelitian survei dengan menggunakan pendekatan kuantitatif. Populasi pada penelitian adalah siswa kelas 8 SMP dengan jumlah 132 siswa. Data pada penelitian ini dikumpulkan menggunakan dua instrumen yaitu tes kemampuan penalaran matematika dan angket self-efficacy. Tes kemampuan penalaran matematika terdiri dari 4 butir soal yang bertujuan untuk mengukur kemampuan penalaran matematika siswa sesuai dengan indikator penalaran yang disusun. Sedangkan, angket self-efficacy terdiri dari 30 butir pernyataan untuk mengukur 3 aspek self-efficacy yaitu level, strength, dan generality.

Validitas yang digunakan pada instrumen penelitian adalah validitas isi oleh expert judgment (2 dosen ahli) dan validitas konstruk khusus untuk angket self-efficacy. Hasil penilaian oleh expert judgment menunjukkan bahwa kedua instrumen valid untuk digunakan untuk mengumpulkan data pada penilitian ini. Validitas konstruk untuk angket self-efficacy menggunkan analisis faktor, yang menunjukkan bahwa nilai Kaiser-Mayer-Olkin Measure of Sampling Adequacy (KMO) yang diperoleh lebih besar dari 0,5 yaitu 0,608. Hal tersebut berarti bahwa semua butir pernyataan pada angket self-efficacy secara keseluruhan valid digunakan ntuk penelitian.

Reliabilitas pada penelitian ini menggunakan rumus Alpha Cronbach dengan rumus,

$$
\begin{aligned}
& r=\frac{k}{k-1}\left(1-\frac{S_{i}^{2}}{S_{t}{ }^{2}}\right) \\
& r=\text { koefisien reliabilitas } \\
& k=\text { banyaknya butir pernyataan } \\
& S_{i}{ }^{2}=\text { variansi setiap butir } \\
& S_{t}{ }^{2}=\text { variansi total }
\end{aligned}
$$

Sehingga diperoleh koefisien reliabilitas intrumen tes kemampuan penalaran matematika dan angket self-efficacy masing-masing 0,756 dan 0,892. Hasil tersebut menunjukkan bahwa koefisien reliabilitas setiap instrumen lebih besar 0,65 yang berarti instrumen reliabel digunakan.

Analisis data pada penelitian ini terdiri dari analisis dekriptif dan analisis inferensial. Hasil analisis deskriptif yang disajikan yaitu: rata-rata, standar deviasi, nilai minimum dan maksimum yang diperoleh siswa. Di samping itu, skor yang diperoleh siswa pada angket selfefficacy dikonvenrsi dari data kuantitatif menjadi data kualitiatif berdasarkan kriteria berikut.

Tabel 1. Kriteria Kualitatif Skor Self-Efficacy

\begin{tabular}{ll}
\hline Nilai & Kriteria \\
\hline$X>120$ & Sangat Tinggi \\
$100<X \leq 120$ & Tinggi \\
$80<X \leq 100$ & Sedang
\end{tabular}




\begin{tabular}{ll}
\hline Nilai & Kriteria \\
\hline $60<X \leq 80$ & Rendah \\
$X \leq 60$ & Sangat Rendah \\
\hline
\end{tabular}

Analisis inferensial yang digunakan adalah uji korelasi Perason product-moment. Uji korelasi bertujuan untuk mengetahui hubungan antara kemampuan penalaaran matematika siswa dan self-efficacy. Koefisien korelasi berada pada rentang -1 sampai 1. Koefisien korelasi semakin mendekati 1 atau -1 menunjukkan bahwa adanya hubungan yang semakin kuat. Sedangkan positif-negatif menentukan arah hubungan variabel yang diuji.

\section{Hasil dan Pembahasan}

Pada penelitian ini, hasil dan pembahasan terdiri dari dua bagian yaitu hasil analisis deskriptif dan analisis inferensial untuk melihat hubungan antara kemampuan penalaran matematika dan self-efficacy. Data kemampuan penalaran matematika dan self-efficacy siswa dapat dilihat pada Tabel 2 dan Tabel 3 berikut.

Tabel 2. Deskripsi Data Kemampuan Penalaran Matematika

\begin{tabular}{ll}
\hline Deksripsi Data & Nilai \\
\hline Rata-Rata & 11,44 \\
Standar Deviasi & 2,49 \\
Skor Maksimum Ideal & 15 \\
Skor Minimum Ideal & 0 \\
Skor Maksimum & 5 \\
Skor Minimum & 15 \\
\hline
\end{tabular}

Tabel 2 menunjukkan deskriptif data kemampuan penalaran matematika dan selfefficacy secara keseluruhan. Rata-rata skor kemampuan penalaran matematika adalah 11,44 di mana skor tersebut sudah mendekati skor maksimum ideal kemampuan penalaran matematika. Hasil analisis deksriptif juga menunjukkan bahwa indikator memberikan bukti yang benar dan lengkap terhadap solusi merupakan indikator yang mempunyai skor rata-rata yang paling tinggi sebesar 3,32, sedangkan indikator membuat atau mengajukan dugaan merupakan indikator dengan rata-rata skor paling rendah sebesar 2,76.

Tabel 3. Deskripsi Data Self-Efficacy

\begin{tabular}{ll}
\hline Deksripsi Data & Nilai \\
\hline Rata-Rata & 101,13 \\
Standar Deviasi & 14,91 \\
Skor Maksimum Ideal & 150 \\
Skor Minimum Ideal & 0 \\
Skor Maksimum & 137
\end{tabular}




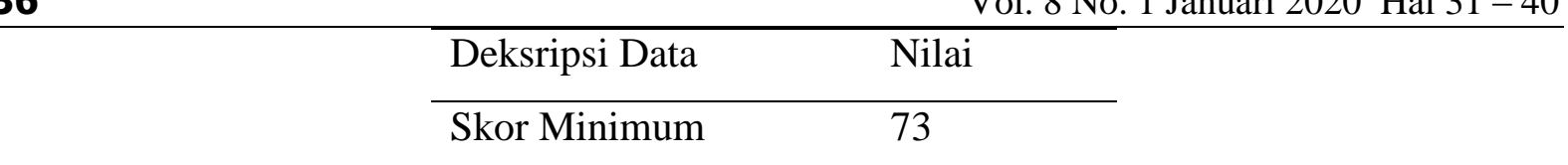

Selanjutnya, hasil analisis deskriptif data self-efficacy ditunjukkan pada Tabel 3, ratarata skor self-efficacy sebesar 101,13 yang berada pada kategori tinggi. Hasil analisis data menunjukkan bahwa aspek strength menjadi dimensi dengan skor rata-rata paling tinggi yaitu sebesar 3,83 dengan rata-rata skor maksimum yaitu 5. Hal ini mengindikasikan bahwa secara umum siswa memiliki tingkat ketahanan dan keuletan yang tinggi dalam menyelesaikan tugas matematika. Sedangkan aspek level merupakan dimensi self-efficacy dengan rata-rata paling rendah yaitu sebesar 2,9. Berdasarkan hasil analisis angket self-efficacy diperoleh informasi bahwa tingkat kesulitan suatu soal atau tugas akan mempengaruhi tingkat self-efficacy siswa. Setiap siswa memiliki tingkat self-efficacy yang berbeda-beda berdasarkan soal yang mereka hadapi. Terkadang ada siswa mempunyai self-efficacy yang tinggi jika diberi tantangan menyelesaikan tugas yang sulit ada ada juga siswa mempunyai tingkat self-efficacy yang tinggi jika mengerjakan soal yang mudah.

Data hasil angket self-efficacy kemudian dikonversikan dari data kuantitatif menjadi data kualitatif. Data kualitatif tersebut terbagi atas lima kriteria yaitu sangat tinggi, tinggi, sedang, rendah, dan sangat rendah. Hasil konversi data angket self-efficacy dapat dilihat pada Tabel 4 berikut.

Tabel 4. Konversi Data Angket Self-Efficacy

\begin{tabular}{llcc}
\hline Skor & Kriteria & \multicolumn{2}{c}{ Persentase } \\
\cline { 3 - 4 } & & Jumlah & Persen (\%) \\
\hline$X>120$ & Sangat Tinggi & 5 & 10 \\
$100<X \leq 120$ & Tinggi & 20 & 42 \\
$80<X \leq 100$ & Sedang & 22 & 46 \\
$60<X \leq 80$ & Rendah & 2 & 2 \\
$X \leq 60$ & Sangat Rendah & 0 & 0
\end{tabular}

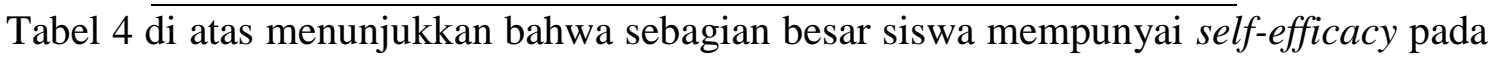
kategori yang cukup tinggi. Hal tersebut terlihat dari ada 20 orang siswa berada pada kategori tinggi dan 5 orang siswa berada pada kategori sangat tinggi. Hal mengindikasikan bahwa siswa yakin dengan kemampuannya sendiri untuk menyelesaikan dengan baik setiap tugas yang mereka hadapi.

Tahap selanjutnya adalah analisis inferensial dengan menggunakan uji korelasi. Namun demikian, sebelum melakukan uji korelasi dengan menggunakan Perason product-moment correlation test ada tiga uji asumsi yang harus dipenuhi yaitu uji normalitas, linearitas, dan 
heteroskedastisitas. Hasil uji normalitas, linearitas, dan heteroskedastisitas dapat dilihat pada Tabel 5, Tabel 6, dan Tabel 7 berikut.

Tabel 5. Uji Normalitas

\begin{tabular}{ccc}
\hline & $p$-value & Keterangan \\
\hline One-Sample Kolmogorov-Smirnov test & 0,079 & Normal \\
\hline
\end{tabular}

Tabel 6. Uji Linearitas

\begin{tabular}{ccc}
\hline & $p$-value & Keterangan \\
\hline Linearity & 0,001 & Linear \\
\hline
\end{tabular}

Tabel 7. Uji Heteroskedastisitas

\begin{tabular}{crl}
\hline & $p$-value & Keterangan \\
\hline Glejser test & 0,011 & Terjadi gelaja heteroskedastisitas
\end{tabular}

Berdasarkan hasil uji asumsi klasik diperoleh bahwa uji normalitas, uji linearitas, dan uji heteroskedastisitas terpenuhi sehingga uji korelasi dengan menggunakan Pearson productmomen untuk melihat hubungan kemampuan penalaran matematika dan self-efficacy siswa dapat dilakukan. Hasil uji korelasi Perason product-momen dapat dilhat pada Tabel 8 berikut.

Tabel 8. Uji Korelasi

\begin{tabular}{ccc}
\hline & Coefisient correlation & P-value \\
\hline Pearson product-momen & 0,556 & 0.000 \\
\hline
\end{tabular}

Hubungan antara kemampuan penalaran matematika dan self-efficacy dapat dililhat dari besar koefisien korelasi. Interpretasi besar koefisien korelasi terbagi atas 6 kelas (Cohen, Manion, \& Morrison, 2007) yaitu:

$$
\begin{aligned}
& 0<r<0,1 \text { : korelasi positif sangat lemah } \\
& 0,1 \leq r<0,3 \text { : korelasi positif lemah } \\
& 0,3 \leq r<0,5 \text { : korelasi positif sedang } \\
& 0,5 \leq r<0,8 \text { : korelasi positif kuat } \\
& 0,8 \leq r<1 \text { : korelasi positif sangat kuat }
\end{aligned}
$$

Berdasarkan Tabel di atas, diperoleh bawah koefisien korelasi sebesar 0,556. Hal berarti bahwa terdapat hubungan yang kuat antara kemampuan penalaran matematika dan selfefficacy. Hubungan antara kemampuan penalaran matematika dan self-efficacy yang terbentuk mempunyai arah hubungan yang positif. Arah hubungan positif berarti bahwa semakin tinggi tingkat self-efficacy siswa, maka akan semakin tinggi juga skor hasil tes kemampuan 
kemampuan penalaran matematika. Sebaliknya, semakin rendah self-efficacy siswa, maka semakin rendah pula skor hasil kemampuan penalaran matematikanya. Hal ini sesuai dengan penelitian (Kitsantas et al., 2011) bahwa siswa dengan self-efficacy rendah cenderung memiliki skor matematika yang rendah serta menghabiskan banyak waktu untuk menyelesaikan soal matematika. Hasil penelitian tersebut sejalan dengan pendapat (Phan, 2012) bahwa self-efficacy yang tinggi memiliki pengaruh yang besar dalam menentukan hasil belajar siswa dalam pembelajaran matematika.

Penelitian lain menunjukkan bahwa prestasi belajar matematika siswa dipengaruhi oleh dua hal yaitu sikap akademis dan self-efficacy. Prestasi belajar yang dimaksud pada penelitian tersebut adalah sejumlah soal yang harus dikerjakan oleh siswa dengan menggunakan kemampuan penalaran matematis (Taat, Muhammad, Rozario, \& Gladys, 2014). Selain itu, siswa yang memiliki self-efficacy yang positif dapat mempengaruh prilaku siswa dalam belajar seperti ketekunan dan fleksibilitas dalam belajar, sehingga secara tidak langsung akan ikut menentukan capaian hasil belajar siswa khususnya kemampuan penalaran matematika (Noer, 2013). Sejalan penelitian yang mengungkapkan bahawa terdapat pengaruh yang kuat self-efficacy dengan kemampuan penalaran matematika (Sanhadi, 2015). Hal ini didukung teori bahwa matematika dan penalaran adalah dua hal yang tidak dapat dipisahkan karena matematika dapat dipahami dengan baik melalui penalaran dan penalaran dapat dilatihkan melalui matematika (Maarif, 2016). Sesuai dengan hasil penelitian lain bahwa siswa dengan self-efficacy tinggi pada jenjang pendidikan dasar akan terus meningkat dan berlanjut pada jenjang pendidikan yang lebih tinggi, sehingga prestasi belajar matematika siswa dipengaruhi secara positif oleh self-efficacy. Dengan demikian, upaya meningkatkan self-efficacy akan sejalan dengan upaya meningkatkan kemampuan-kemampuan matematika seperti kemampuan penalaran matematika. Sejalan dengan hal tersebut, penyelenggara pembelajaran misalnya guru seharusnya memfasilitasi siswa untuk menyelesaikan masalah-masalah matematika yang lebih memerlukan aplikasi teori, teorema, prinsip, sifat matematika sehingga menstimulus self-efficacy siswa (Dinther, Dochy, \& Segers, 2011).

\section{Kesimpulan}

Berdasarkan hasil penelitian diperoleh informasi bahwa kemampuan penalaran matematika siswa dalam memberikan bukti yang benar dan lengkap terhadap solusi mempunyai skor ratarata yang paling tinggi sebesar 3,32, sedangkan kemampuan membuat atau mengajukan dugaan merupakan indikator dengan rata-rata skor paling rendah sebesar 2,76. Sementara itu, rata-rata skor self-efficacy berada pada kategori tinggi. Hasil analisis data menunjukkan bahwa 
aspek strength menjadi dimensi dengan skor rata-rata paling tinggi yaitu sebesar 3,83 dengan skor maksimum ideal 5.

Berdasarkan hasil analisis inferensial dapat disimpulkan bahwa terdapat hubungan yang cukup kuat antara kemampuan penalaran matematika dan self-efficacy. Hubungan yang diperoleh adalah hubungan dengan arah positif. Ini berarti bahwa semakin tinggi self-efficacy siswa, semakin tinggi pula kemampuan penalaran matematika. Lebih jauh berdasarkan hasil penelitian pada artikel ini, peneliti lain dapat menyusun strategi pembelajaran yang dianggap tepat untuk menstimulus self-efficacy siswa dan kemampuan penalaran matematika. selain itu, peneliti lain juga dapat mengembangkan bahan ajar atau perangkat pembelajaran untuk meningkatkan self-efficacy dan kemampuan penalaran matematika siswa.

\section{Pustaka}

Aprisal, A., \& Abadi, A. M. (2018a). Improving student's mathematical reasoning and selfefficacy through Missouri mathematics project and problem solving. Beta: Jurnal Tadris Matematika, 11(2), 191-208. https://doi.org/10.20414/betajtm.v11i2.206

Aprisal, A., \& Abadi, A. M. (2018b). Mathematical communication ability of students viewed from self-efficacy. In International Conference on Mathematics and Science Education of Universitas Pendidikan Indonesia (pp. 726-732). Retrieved from http://science.conference.upi.edu/proceeding/index.php/ICMScE/article/view/20

Bandura, A. (2009). Self-efficacy in changing societies. Cambridge: Cambridge University Pres.

Betz, N. E., \& Hackett, G. (1983). The relationship of mathematics self-efficacy expectation to the selection of science-based collage mayors. Journal of Vocational Bhaviour, 23(3), 329-345.

Cohen, L., Manion, L., \& Morrison, K. (2007). Research methods in education (6th ed.). London: Routledge.

Conner, A. M., Singletary, L. M., Smith, R. C., Wagner, P. A., \& Fransisco, R. T. (2014). Identifying kind of reasoning in collective argumentation. Mathematical Thinking and Learning, 163(3), 181-200. https://doi.org/10.1080/10986065.2014.921131

Depdiknas. (2006). Peraturan Menteri Pendidikan Nasional RI No 22 Tahun 2006, tentang Standar Isi.

Dinther, M. Van, Dochy, F., \& Segers, M. (2011). Factors affecting students' selfefficacy in higher education. Educational Research Review, 6(2), 95-108. https://doi.org/10.1016/j.edurev.2010.10.003

John, P., \& Mst, B. O. (2016). Logical Reasoning Abilities of Junior High School Students in the Province of Cotabato, Philippines, 4(4), 18-21.

Kitsantas, A., Cheema, J., \& Ware, H. W. (2011). Mathematics achievement: the role of homework and self-efficacy beliefs. Journal of Advanced Academics, 22(2), 310-339.

Lau, C., Kitsantas, A., Miller, A. D., \& Rodgers, E. B. D. (2018). Perceived responsivity for learning, self-efficacy, and sources of self-efficacy in mathematics: A study international baccalaureate primary years programs students. Social Psychology Education, 21(3), 603-620. https://doi.org/10.1007/s11218-018- 9431-4

Lim, K., Kim, O. K., Cordero, F., Buendia, G., \& Kasmer, L. (2015). The use of prediction in mathematics classroom. Retrieved from https://www.researchgate.net/publication/267804444_THE_USE_OF_PREDICTION_I N_MATHE\%0AMATICS_CLASSROOMS

Maarif, S. (2016). Improving Junior High School Students' Mathematical Analogical Ability 
Using Discovery Learning Method Improving Junior High School Students Mathematical Analogical Ability U sing.

Malpass, J., O'neil, H. F., \& Hocevar, D. (2010). Self-regulation, goal orientation, selfefficacy, worry, and high-stakes math achievment for mathematically gifted high school student. Roper Review, 21(4), 281-288.

Mullis, I. V. S., Martin, M. O., Hoy, P., \& Arora, A. (2012). TIMMS 2011 international result in mathematics. Chestnutt Hill, MA: TIMsS \& PIRLS International Study Center, Boston Collage.

NCTM. (2000). Principle and standards for school mathematics. Reston, VA: NCTM.

Noer, S. H. (2013). Self-efficacy mahasiswa terhadap matematika.

Phan, H. P. (2012). Relation between informational sources, self-efficacy and academic achievement: a development approach. Educational Psychology: An International Journal of Experimental Educational Psychology, 32(1), 81-105. https://doi.org/10.1080/01443410.2011.625612

Sanhadi, K. C. D. (2015). Pengaruh kemampuan penalaran dan self-efficacy terhadap hasil belajar matematika siswa Kelas VIII. In SEMINAR NASIONAL MATEMATIKA DAN PENDIDIKAN MATEMATIKA UNY 2015 (pp. 341-350).

Santrock, J. W. (2011). Educational psychology (5th ed). New York: McGraw Hill Companies.

Schunk, D. H., \& Meece, J. . (2006). Self-efficacy development in adolescence. In Selfefficacy beliefs of adolescencents (pp. 71-96). Information Age Publishing.

Taat, Muhammad, S., Rozario, \& Gladys, D. (2014). The influence of academic attitude and self-efficacy towards students' achievement in private higher learning institution. International Journal of Arts and Commerce, 3(6), 41-50. 